\author{
Magdalena JARCZOK-GUZY, PhD \\ Collegium of Finance, University of Economics in Katowice \\ e-mail: magdalena.guzy@ue.katowice.pl \\ ORCID: 0000-0001-9373-1264
}

DOI: $10.15290 /$ oes.2020.03.101.06

\title{
ORGANIC PAYMENTS AS A FORM OF SUPPORT FOR ORGANIC AGRICULTURE IN POLAND ${ }^{1}$
}

\begin{abstract}
Summary
Purpose - The purpose of this article is to conduct empirical research which contributes to determining the interest in enjoying organic payments made to farmers under the "Rural Areas Development Program" in the area of the Framework Action Plan for Organic Food and Farming in Poland.

Research method - The method of a literature review and analysis coupled with statistical analysis based on the calculation of structure, dynamics and correlation indicators were used in the work. The dynamics of organic payments received by farmers during the period 2014-2018 was assessed. A comparison was also made of the value of organic farming payments with budget expenditure on agriculture in Poland.

Results - The obtained correlation coefficients were utilised to assess the relationship between the expenditure under the program and the expenditure of the state budget on agriculture. The correlation coefficient calculated for the number of beneficiaries and the value of ecological payments is 0.17201 . The correlation coefficient for the value of organic payments and the value of budget expenditure on agriculture and hunting is -0.3406167 .

Originality / value/ implications / recommendations - An attempt was made to evaluate the role of organic payments in Poland as a form of motivating farmers to undertake organic production. Since 2014, the number of organic processing plants has increased by $88 \%$. The decrease in the number of producers and increase in the number of processing plants may indicate a change in the structure of the supply chain in the area of organic food.
\end{abstract}

Keywords: organic payments, Rural Development Programme, organic farming

JEL Classification: H23, H51, H71

\section{Introduction}

Agriculture constitutes an important element of the national economy in Poland. In the last decade, the idea of organic farming has drawn specific interest. This form of farming activity has been treated in a particular way by public authorities, both in Poland and within the EU. Agriculture, especially organic farming, is one of the key

${ }_{1}$ Article received on 19 March 2020, accepted on 20 April 2020. 
pillars necessary for sustainable development. This article focuses on organic payments. Due to its special nature, only this method of support has been selected for analysis, and this is discussed in the first part of this paper. This character results not only from the period for which the funds are allocated, but largely as farmers undertake to pursue organic farming for a period of 5 years. Furthermore, the paper also describes the characteristics of organic farming. The third section of the article includes a statistical analysis of budgetary expenditures for agriculture and the disbursed organic payments. The research method applied in the study consists of an analysis of the subject literature, as well as an analysis of performance reports between 2014-2018 with respect to the disbursed organic payments and reports from the state budget performance for the same period. The research period selected for the purpose of the analysis is related to the availability of a full scope of data thus allowing for a diligent analysis.

The conducted statistical analysis is a presentation of the level of payments disbursed to organic farmers included in the programme. It will help define the direction of changes with respect to the popularity of such payments amongst Polish farmers. The result of the analysis is the presentation of organic payments and the definition of their volume in comparison to other forms of agricultural support in Poland. The correlation coefficient defines the character of relationships and helps define the interest among farmers to use this form of financial support. The research hypothesis is as follows: as the number of the beneficiaries' increase, the amount of organic payments also rises.

\section{Organic payments}

In Poland, the sources of financing pro-organic agriculture can be divided into 3 principal groups [Janiak et al., 2018, p. 71]:

a) EU funds, including:

- Rural Development Programme for 2014-2020, including the "Framework Action Plan for Organic Food and Farming in Poland", as per the information from ARiMR (Agency for Restructuring and Modernisation of Agriculture) [www 2],

- Mechanisms of the Common Agricultural Policy: support for promotion and information activities concerning markets of selected agricultural products.

b) Domestic funds:

- Agricultural advisory provided by Agricultural Advisory Centres,

- Information and promotion activities run by the Ministry of Agriculture and Rural Development. These activities are conducted in cooperation with organic farming organisations.

c) Preferential loans:

- Since 2015, the Agency for Restructuring and Modernisation of Agriculture has cooperated with 7 banks with respect to subsidies to loans, 
- Natural disaster loans,

- Loans granted by other banks, most frequently referred to as investment loans or advances.

Likewise, organic payments are also offered to farmers as part of the aforementioned "Framework Action Plan for Organic Food and Agriculture",

Within the Rural Development Programme (PROW) for 2014-2020, organic producers were eligible to apply for financial support according to general principles within all measures, if such principles provide for support farmers or processing plants. However, it should be stressed that there are also special activities for organic producers, and other measures providing for preferences for organic production. Within PROW 2014-2020, organic producers may obtain support relevant for the area of arable land used for farming in compliance with the regulations on the organic farming as part of the measure: "Organic Farming". The funds available for this measure from PROW 2014-2020 amount to ca. EUR 700 million (almost PLN 3 billion). The scope of the measure "Organic Farming" includes the support of voluntary commitments of farmers who undertake to maintain or converse towards organic farming practices and methods, as defined the Council Regulation (EC) No. 834/2007. All arable plots declared for financial support within the measure: "Organic Farming" are subject to control by authorised certifying bodies. A beneficiary can be any professionally active farmer owning a farm of no less than 1 ha within the territory of Poland, who agrees to follow the regulations of the measure "Organic Farming" for 5 years, as well as to follow the requirements resulting from individual packages/options of this measure. The form of financial support referred to above is an "organic farming payment" [www 2].

The support is allocated within two sub-measures, which include the following packages:

Sub-measure 1 - Payments during conversion towards organic farming [www 3]:

- Package 1. Agriculture farming during conversion

- Package 2. Vegetable growing during conversion

- Package 3. Herb growing during conversion

- Package 4. Fruit growing during conversion

- Package 5. Animal feed growing on arable land during conversion

- Package 6. Permanent grassland growing during conversion.

Sub-measure 2 - Payments to maintain organic farming:

- Package 7. Agriculture farming after conversion

- Package 8. Vegetable growing after conversion

- Package 9. Herb growing after conversion

- Package 10. Fruit growing after conversion

- Package 11. Animal feed growing on arable land after conversion

- Package 12. Permanent grassland growing after conversion.

Table 1 shows the rates of organic payments. 
TABLE 1

Rates of organic payments 2014-2020

\begin{tabular}{|c|c|c|c|}
\hline No. & Packages of organic farming & Variants of organic farming & Payment rates \\
\hline 1 & \multirow{3}{*}{\multicolumn{2}{|c|}{$\begin{array}{l}\text { Package 1. Agriculture farming during conversion } \\
\text { Package 2. Vegetable growing during conversion } \\
\text { Package } 3 \text {. Herb growing during conversion }\end{array}$}} & $966 \mathrm{PLN} / \mathrm{ha}$ \\
\hline 2 & & & $1557 \mathrm{PLN} / \mathrm{ha}$ \\
\hline 3 & & & $1325 \mathrm{PLN} / \mathrm{ha}$ \\
\hline \multirow[t]{3}{*}{4} & $\begin{array}{l}\text { Package 4. Fruit growing } \\
\text { during conversion }\end{array}$ & $\begin{array}{l}\text { 4.1.1. Principal fruit growing } \\
\text { during conversion }\end{array}$ & $1882 \mathrm{PLN} / \mathrm{ha}$ \\
\hline & & $\begin{array}{l}\text { 4.1.2. Berry fruit growing } \\
\text { during conversion }\end{array}$ & $1882 \mathrm{PLN} / \mathrm{ha}$ \\
\hline & & $\begin{array}{l}\text { 4.2. Extensive fruit growing } \\
\text { during conversion }\end{array}$ & $790 \mathrm{PLN} / \mathrm{ha}$ \\
\hline 5 & \multicolumn{2}{|c|}{$\begin{array}{l}\text { Package } 5 \text {. Animal feed growing on arable land during } \\
\text { conversion }\end{array}$} & 787 PLN/ha \\
\hline 6 & \multicolumn{2}{|c|}{ Package 6. Permanent grassland growing during conversion } & $428 \mathrm{PLN} / \mathrm{ha}$ \\
\hline 7 & \multicolumn{2}{|c|}{ Package 7 . Agriculture farming after conversion } & $792 \mathrm{PLN} / \mathrm{ha}$ \\
\hline 8 & \multicolumn{2}{|c|}{ Package 8. Vegetable growing after conversion } & $1310 \mathrm{PLN} / \mathrm{ha}$ \\
\hline 9 & \multicolumn{2}{|c|}{ Package 9. Herb growing after conversion } & $1325 \mathrm{PLN} / \mathrm{ha}$ \\
\hline \multirow[t]{3}{*}{10} & $\begin{array}{l}\text { Package } 10 \text {. Fruit growing } \\
\text { after conversion }\end{array}$ & $\begin{array}{l}\text { 10.1.1. Principal fruit growing } \\
\text { after conversion }\end{array}$ & $1501 \mathrm{PLN} / \mathrm{ha}$ \\
\hline & & $\begin{array}{l}\text { 10.1.2 Berry fruit growing } \\
\text { after conversion }\end{array}$ & $1501 \mathrm{PLN} / \mathrm{ha}$ \\
\hline & & $\begin{array}{l}\text { 10.2. Extensive fruit growing } \\
\text { after conversion }\end{array}$ & $660 \mathrm{PLN} / \mathrm{ha}$ \\
\hline 11 & \multicolumn{2}{|c|}{$\begin{array}{l}\text { Package 11. Animal feed growing on arable land after } \\
\text { conversion }\end{array}$} & $669 \mathrm{PLN} / \mathrm{ha}$ \\
\hline 12 & \multicolumn{2}{|c|}{ Package 12. Permanent grassland growing after conversion } & $428 \mathrm{PLN} / \mathrm{ha}$ \\
\hline
\end{tabular}

Source: [www 3].

Within both sub-measures, the organic farming payment is allocated at the amount of [www 3]:

- $\quad 100 \%$ of the basic rate - for land measuring from 0,10 ha to 50 ha,

- $\quad 75 \%$ of the basic rate - for land measuring from 50 ha to 100 ha,

- $\quad 60 \%$ of the basic rate - for land measuring more than 100 ha.

Providing financial support in the form of organic payments is regulated by acts of law defining obligations of both the paying bodies and beneficiaries [Act, 2015].

\section{Organic farming}

The tradition of organic farming in Poland dates back to pre-war times. The pioneers of organic farming in Poland were Count and Countess von Keyserlingk who lived in Kobierzyce (then Koberwitz, Germany) in 1920-1928. Count Stanisław 
Karłowski, a senator at the time of interwar Poland of the Second Polish Republic, was also an advocate of the biodynamic concept in agriculture and operated his farm in Szelejewo near Gostyń according to the principles of biodynamics. After the Second World War, the idea of organic farming was mostly abandoned, with the exception of the achievements of Julian Osetek, Eng. who for several years applied the biodynamic method at his 3 ha farm in Nakło nad Notecia (Nakel an der Netze). His theories gained popularity again in the 1980s. Following the initiative of Prof. Mieczysław Górny, the first course of biodynamic farming was organised in Warsaw in 1984. As a result of such pioneering activities, the Association of Organic Food Producers (now EKOLAND) was officially registered on the $1{ }^{\text {st }}$ September 1984; its members were farmers and scientists who were dedicated to the idea of organic farming. On the same day, a meeting of activists of the "eco-agro" movement from the countries of the then eastern block was held. Poland hosted the meeting which gathered representatives from Hungary, Czechoslovakia, East Germany, and the Lithuanian Republic. The meeting was initiated by the International Federation of Organic Agriculture Movements (IFOAM). Knowledge about organic methods of farming and animal breeding was popularised among Polish farmers by the EKOLAND Association, who developed training projects and organic publications in cooperation with German partners: Heinrich Böll Foundation from Kölne and Leben Und Umwelt from Lower Saxony [Duda-Krynicka, Jaskólecki, 2010, p. 87].

In Poland, the system of control and certification of organic farming and processing is mixed, i.e. it involves the state and the private sector. In comprises the following parties [Euczka-Bakuła, 2007, p. 164]:

- Ministry of Agriculture and Rural Areas, as the office authorising private certifying units to conduct controls and issue certificates.

- Main Inspectorate of Trade Quality of Food and Agriculture Products, which serves the function of a supervisory body over certifying entities.

- Certifying entities accredited according to the PN-EN/45011 standard by the Polish Centre for Accreditation and authorised by the Ministry of Agriculture and Rural Development to conduct controls and issue certificates.

According to Szołtysek [2004, p. 22], organic food is defined as food which

- has been produced on farms holding a legal certificate (in optimum environmental conditions and by use of methods which maintain harmony with the environment),

- has been processed using methods preserving their maximum nutritious properties,

- has been processed and stored without preservatives, artificial colourings and/or other additives; is packed in bio-recyclable packages (e.g. drinks, milk and dairy products may be sold only in glass containers).

The double character of the organic farming system is frequently underlined. First, it is a system which has a positive impact on the natural environment, and it contributes to its balance. On the other hand, organic farming is responsible for changing the structure of demand on the market. Consumers are inclined to buy organic products, they want to purchase them even at prices which are usually higher 
than in the case of products which were not produced with the use of organic methods [Biernat-Jarka, Trębska, 2018, p. 40].

The greening process of Polish farming may be analysed in terms of institutional economics and public choice theory. It can be justified since the moment of introduction of intervention instruments within the Common Agricultural Policy in 2004, the greening process has accelerated considerably. The foundation of directing the agricultural policy and implementation of financial aid for organic farming is the change of CAP priorities in the direction of mitigating climate change, a need to undertake actions for environment protection, or providing food security and food safety [Brodzińska, 2018, p 50].

According to the Council Regulation (EC) No. 834/2007 of 28 June 2007 on organic production and labelling of organic products and repealing Regulation (EEC) No 2092/91, with the exception of producing high quality safe food, the purpose of organic production is creating a sustainable system of agriculture management which [Marszałek, 2018, p. 56]:

- respects nature's systems and cycles, and sustains and enhances the health of water, soil, plants, and animals, and the balance between them,

- contributes to a high level of biological diversity,

- respects high animal welfare standards and meets animals' species-specific behavioural needs,

- $\quad$ makes responsible use of energy and natural resources (water, soil, and air).

One of numerous symbols of certificates, which are placed by producers on food product labels is the symbol of organic farming. The EU logo for food products originating from certified organic production and breeding, i.e. the "Euro-leaf", was introduced with the Commission Regulation EU) No. 271/2010 of 24 March 2010 [Kaczorowska et al., 2018, p. 197]. The colour of the background is bright green, and the elements forming the shape of the leaf are white (chart 1). It is permitted to apply other shades and greys.

CHART 1

\section{EU logo for identifying certified organic food - allowed forms}

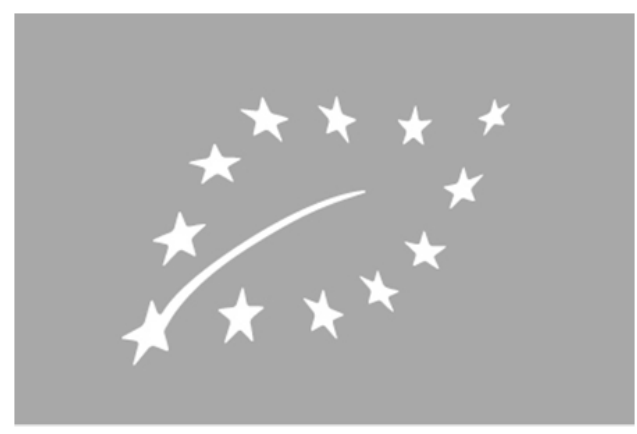

Source: [www 6]. 
The sate of ecological awareness, in particular the recognition of threats of nature's degradation in relation to human life conditions and quality, influences the system of consumers' motivation, which is the causative factor of pro-ecological activities. The higher the consumers' awareness of risks that may influence them, the stronger they feel the impact of factors stimulating pro-ecological behaviour. If there is no awareness of risks related to the degradation of the natural environment and its impact on health, there will not be any pro-ecological action. The risk awareness is the strongest, although not the sole factor influencing pro-ecological behaviour. It depends on a number of diversified factors, including first of all the development of organic products market, consumers' affluence, the condition of environmental infrastructure, and also the environment-friendly policy of the state [Luczka-Bakuła, 2011, p. 52].

\section{Analysis of organic payments in 2014-2018}

This part of the article presents a statistical analysis of disbursed organic payments designated for farmers who committed to organic farming. The table below indicates the amount of payments received by farmers in the period 2014-2018 (table 2).

TABLE 2

Amount of organic payments received by farmers in 2014-2018

\begin{tabular}{|c|c|c|c|}
\hline Reporting period & $\begin{array}{c}\text { Amount of organic } \\
\text { payments in millions } \\
\text { PLN }\end{array}$ & $\begin{array}{c}\text { Dynamics } \\
\text { indicator } \\
\text { in comparison } \\
\text { to the base year }\end{array}$ & $\begin{array}{c}\text { Dynamics } \\
\text { indicator } \\
\text { in comparison } \\
\text { to the previous year }\end{array}$ \\
\hline 2014 & 335.45 & - & - \\
2015 & 264.34 & $-21.2 \%$ & $-21.2 \%$ \\
2016 & 344 & $2.8 \%$ & $30.1 \%$ \\
2017 & 318.75 & $-4.9 \%$ & $-7.3 \%$ \\
2018 & 290.96 & $-12.9 \%$ & $-8.7 \%$ \\
\hline
\end{tabular}

Source: [www 3].

Pursuant to data in table 2 it is possible to conclude that the amount of funds disbursed with the "Organic farming" measure differed in individual years. To complement the analysis, data is presented below from state budget reports concerning the value of public expenditure for agriculture in the period adopted for the analysis (table 3). According to the data (tables 2,3), calculations were made to determine the correlation coefficient for organic payments and the amount of budgetary expenditure for agriculture and hunting. The calculations were made according to the following formula [Ostasiewicz et al., 2003, p. 310]:

$$
r_{x y}=\frac{\sum_{i=1}^{n}\left(x_{i}-\bar{x}\right)\left(y_{i}-\bar{y}\right)}{\sqrt{\sum_{i=1}^{n}\left(x_{i}-\bar{x}\right)^{2}} \sqrt{\sum_{i=1}^{n}\left(y_{i}-\bar{y}\right)^{2}}},
$$


TABLE 3

Budgetary expenditure for agriculture and hunting 2014-2018

\begin{tabular}{|c|c|c|c|}
\hline Reporting period & $\begin{array}{c}\text { Budgetary expenses } \\
\text { in thousands PLN }\end{array}$ & $\begin{array}{c}\text { Dynamics } \\
\text { indicator } \\
\text { in comparison } \\
\text { to the base year }\end{array}$ & $\begin{array}{c}\text { Dynamics } \\
\text { indicator in } \\
\text { comparison to } \\
\text { the previous year }\end{array}$ \\
\hline 2014 & 8617350 & - & - \\
2015 & 7856548 & $-8.8 \%$ & $-8.8 \%$ \\
2016 & 6922477 & $-19.7 \%$ & $-11.9 \%$ \\
2017 & 7453664 & $-13.5 \%$ & $7.7 \%$ \\
2018 & 8963240 & $4.0 \%$ & $20.2 \%$ \\
\hline
\end{tabular}

Source: author's own elaboration according to: [www 4; www 5].

The result of correlation between the analysed data amounts to -0.3406167 . This is evidence of a low dependence. Therefore, when one of the variables increases, the other one decreases. The next stage is the analysis of the structure of organic payments' share in the subtotal of budgetary expenditures for agriculture and hunting in individual years.

TABLE 4

\section{Structure indicators}

\begin{tabular}{|c|c|c|c|}
\hline Reporting period & $\begin{array}{c}\text { Amount of budgetary } \\
\text { expenditures } \\
\text { in thousands PLN }\end{array}$ & $\begin{array}{c}\text { Amount of organic } \\
\text { payments in } \\
\text { thousands PLN }\end{array}$ & $\begin{array}{c}\text { Structure } \\
\text { indicators }\end{array}$ \\
\hline 2014 & 8617350 & 335450 & $3.9 \%$ \\
2015 & 7856548 & 264340 & $3.4 \%$ \\
2016 & 6922477 & 344000 & $5.0 \%$ \\
2017 & 7453664 & 318750 & $4.3 \%$ \\
2018 & 8963240 & 290960 & $3.2 \%$ \\
\hline
\end{tabular}

Source: author's own elaboration according to: [www 4; www 5].

According to the structure indicators (table 4) it should be noticed that the share of organic payments in all budgetary expenditures for agriculture and hunting were highest in 2016 (5\%). In general, the share of payments was at a similar level in all periods analysed.

Another question is the number of beneficiaries who benefited from the organic payments in the period studied. Table 5 presents the data on the number of organic payment beneficiaries.

The largest increase of the number of organic payment beneficiaries (table 5) occurred in 2017. The correlation coefficient calculated for the number of beneficiaries and the amount of disbursed organic payments amounts to 0.17201. It indicates an absence of linear dependency. This signifies that the amount of organic payments 
does not increase parallel to the number of beneficiaries. It may result from the fact that the beneficiaries receive various amounts of organic payments dependant on the number of hectares defined in the organic payment application and the type of agricultural activity. Thus, the hypothesis has been verified and rejected.

TABLE 5

Number of beneficiaries of organic payment 2014-2018

\begin{tabular}{|c|c|c|c|}
\hline Reporting period & $\begin{array}{c}\text { Number } \\
\text { of beneficiaries } \\
\text { in thousands }\end{array}$ & $\begin{array}{c}\text { Dynamics indicator } \\
\text { in comparison } \\
\text { to the base year }\end{array}$ & $\begin{array}{c}\text { Dynamics indicator } \\
\text { in comparison } \\
\text { to the previous year }\end{array}$ \\
\hline 2014 & 16.8 & - & - \\
2015 & 16.5 & $-1.8 \%$ & $-1.8 \%$ \\
2016 & 17.2 & $2.4 \%$ & $4.2 \%$ \\
2017 & 19.7 & $17.3 \%$ & $14.5 \%$ \\
2018 & 17.9 & $6.5 \%$ & $-9.1 \%$ \\
\hline
\end{tabular}

Source: [www 3].

\section{Conclusions}

Organic payments disbursed within the "Framework Action Plan for Organic Food and Farming in Poland" undoubtedly constitute a form of incentive for farmers who commit to pursue organic farming for a period of 5 years. It is a particularly important instrument which supports farmers in that respect. However, data transpiring from the report of the Supreme Audit Office is disturbing. They indicate that the number of organic farms in Poland decreased during the period studied. The number of farmers undertaking organic farming has decreased by $19 \%$ since 2014, and in 2018 it amounted to 20,549. Concurrently, since 2014, the number of organic processing plants demonstrated an increase of $88 \%$. The reduction in the number of producers and the increase in the number of processing plants may be the evidence of obtaining ecological raw materials from import from other EU countries or from other areas [www 1]. Undoubtedly, the financial support is necessary to maintain organic farming in Poland. Unfortunately, it is not the only determinant factor for the development of this aspect of agriculture. Other factors, including economic ones, influence decisions to converse a farm towards organic production. It is also important to take into consideration that the purpose of organic payments is to compensate farmers for the "lost revenue" resulting from, for example, extensive production methods including elimination of plant protection products. 


\section{References}

Act, 2015, Ustawa z dnia 20 lutego 2015 r. o wspieraniu rozwoju obszarów wiejskich z udziałem środków Europejskiego Funduszu Rolnego na rzecz Rozwoju Obszarów Wiejskich w ramach Programu Rozwoju Obszarów Wiejskich na lata 2014-2020, Dz. U., 2019, poz. 83.

Biernat-Jarka A., Trębska P., 2018, The importance of organic farming in the context of sustainable development of rural areas in Poland, "Acta Scientarum Polonorum Oeconomia”, vol. 17(2), pp. 39-47, DOI: 10.22630/ASPE.2018.17.2.19.

Brodzińska K., 2018, Ekologizacja rolnictwa w aspekcie polityki finansowego wsparcia, „Zeszyty Naukowe SGGW - Problemy Rolnictwa Swiatowego", t. 18(XXXIII)(3), s. 49-58, DOI:10.22630/PRS.2018.18.3.65.

Duda-Krynicka M., Jaskólecki H., 2010, Historia i perspektywy rozwoju rolnictwa ekologicznego w Polsce, „Problemy Ekologii”, vol.14(2), pp. 85-91.

Janiak R., Tokarski A., Motykiewicz M., Dąbrowski A., 2018, Źródta finansowania proekologicznej produkcji rolnej, „Systems Supporting Production Engineering”, vol. 7(2), s. 65-75.

Kaczorowska J., Rejman K., Halicka E., 2018, Wpkyw certyfikatu rolnictwa ekologicznego na gotowość konsumentów do zapłaty wyższej ceny za owoce, „Handel Wewnętrzny”, nr 3(374), s. 197-207.

Luczka-Bakuła W., 2007, Rynek ṡymności ekologicznej: myznaczniki i uwarunkowania rozwoju, Polskie Wydawnictwo Ekonomiczne, Warszawa.

Luczka-Bakuła W., 2011, Decyże zakupu na rynku śywności a śniadomość $i$ zachowania proekologiczne konsumentów, „Handel Wewnętrzny”, nr 3, s. 52-59.

Marszałek A., 2018, Rolnictwo i żynność ekologiczna jako sz̧ansa dla zrónnoważonego rozwoju obszarón wiejskich, „Problemy Drobnych Gospodarstw Rolnych”, nr 4, s. 51-68, DOI: 10.15576/PDGR/2018.4.51.

Ostasiewicz S., Rusnak Z., Siedlecka U., 2003, Statystyka. Elementy teorii $i$ zadania, Wydawnictwo Akademii Ekonomicznej im. Oskara Langego we Wrocławiu, Wrocław.

Szołtysek K., 2004, Zarys problematyki ṡymności ekologicznej, Wydawnictwo Akademii Ekonomicznej im. Oskara Langego, Wrocław.

www 1, https://www.nik.gov.pl/plik/id,21449,v,artykul_20420.pdf [date of entry: 19.02.2020].

www 2, https://www.gov.pl/web/rolnictwo/ramowy-plan-dzialan-dla-ywnosci-irolnictwa-ekologicznego-w-polsce [date of entry: 12.02.2020].

www 3, https://www.gov.pl/web/rolnictwo/ramowy-plan-dzialan-dla-ywnosci-irolnictwa-ekologicznego-w-polsce [date of entry: 12.02.2020].

www 4, https://www.gov.pl/web/finanse/sprawozdanie-roczne-za-2018 [date of entry: 12.02.2020].

www 5, https://mf-arch2.mf.gov.pl/web/bip/ministerstwo-finansow/dzialalnosc/ finanse-publiczne/budzet-panstwa/wykonanie-budzetu-panstwa/sprawozdaniez-wykonania-budzetu-panstwa-roczne/-/asset_publisher/R79o/content/6403938 
?redirect $=$ https $\% 3 \mathrm{~A} \% 2 \mathrm{~F} \% 2 \mathrm{Fmf}$-arch2. mf.gov.pl $\% 2 \mathrm{Fweb} \% 2 \mathrm{Fbip} \% 2 \mathrm{Fminister}$ stwo-finansow $\% 2 \mathrm{Fdzialalnosc} \% 2 \mathrm{~F}$ finanse-publiczne $\% 2$ Fbudzet-panstwa $\% 2 \mathrm{~F}$ wykonanie-budzetu-panstwa $\% 2$ Fsprawozdanie-z-wykonania-budzetu-panstwaroczne $\% 3$ Fp_P_id $\% 3 D 101$ INSTANCE_R79o $\% 26$ p_p_lifecycle $\% 3 \mathrm{D} 0 \% 26$ p_p _state $\% 3$ Dnormal $\% 26$ p_p_mode $\% 3$ Dview $\% 26$ p_p_col_id $\% 3$ Dcolumn-2\%26p _P_col_count $\% 3$ D1\#p_P_id_101_INSTANCE_R79o_[date of entry: 11.02. 2020].

www 6, http://organic-farming.europa.eu [date of entry: 12.02.2020]. 